\title{
Externalities of the EU Immigration and Asylum Policy: The Case of Ukraine
}

\author{
Lyubov Zhyznomirska
}

\begin{abstract}
Since the 1990s, the EU has been gradually transferring to neighbouring countries parts of the burden of securing its internal order from illegal migrants, terrorists, criminal groups and other "threats." It has done so using policy transfers and foreign relations mechanisms. The European Union, seeking to create an "area of freedom, security, and justice" in the region, exports the burden of migration management to its neighbouring countries and thus creates security threats if not real then perceived - for these countries. The case of Ukraine demonstrates that EU policies of shifting the burden of international migration management to its neighbours can destabilize the societal security of countries that lack the experience and instruments to effectively deal with migration. Rather than shifting the burden of responsibility to the neighbouring states, the EU should prioritize co-operation and assistance to expand the area of freedom, justice and security on the European continent.
\end{abstract}




\section{Introduction}

The securitization of migration in the European Union (EU) since the 1980s has received a great deal of attention from scholars (see Huysmans, 2000; Mitsilegas et al., 2003; Tsoukala, 2005; Wœver et al., 1993; Wœver, 1996). From nationalists to welfare chauvinists, immigrants are blamed for undermining national unity, ethnic purity, and social cohesiveness, and for abusing social security programs. The securitization of migration (understood as the discursive construction of migration as a security issue in political discourse) and a depiction of immigration as a threat to the EU societies have provoked confusions between immigrants and asylum-seekers, as well as between legal and illegal immigrants. ${ }^{1}$ More recently, the figure of "the foreigner" has been associated, through security discourse, with Islamic fundamentalism and the threat of terrorism. Such discursive linkages have caused a highly defensive and exclusive approach to European migration management in which an emphasis is placed on control (both internal and external), policing, surveillance, and containment. ${ }^{2}$ Faced with difficult decisions in managing migration, European governments have sought international cooperation on the issue.

The EU migration regime, created through harmonization of immigration and asylum policies among member-states, can be understood as an "entirety of formal and informal directives, regulations, practices, and conventions adopted at the level of EU institutions that regulate the movement of persons across borders and the entry and stay of non-EU nationals in

\footnotetext{
${ }^{1}$ In this paper, I use the concept 'migration' in its general meaning as the movement of people from one country or locality to another. Consequently, the concept 'migrant' generally denotes the categories of "people on the move" immigrants, asylum-seekers, and refugees. In particular cases, the terms 'immigrant' and 'asylum-seeker' are used. ${ }^{2}$ Immigrants are portrayed as "security threats” whose control necessitates harmonized and strict identity controls at EU borders and beyond. Bort calls this strategy a "spatial approach to security and control” (2005: 64).
} 
the common territory” (Lavenex and Uçarer, 2003: 3). Such a regime, it has been argued, affects policy-making in the Union's member-states, candidate states, and non-candidate states. Since the 1990s, the European Union has gradually been transferring the burden of securing its internal order from illegal immigrants, terrorists, criminal groups, and other "threats" to its neighbouring countries using policy transfers and foreign relations mechanisms. As a result, the EU's neighbours have been under pressure to adopt policies and institutions that would secure EU borders and control its unwanted immigration (Lavenex and Uçarer 2003, 2004). ${ }^{3}$ Hence, the Union's internal security measures have been transferred to the external relations framework.

This paper focuses on how the EU policies on immigration and asylum, as well as intensified co-operation among member-states in the area of Justice and Home Affairs (JHA), have been producing external policy effects on non-member states. My argument is that the EU, seeking to create an "area of freedom, security, and justice,” exports the burden of migration management to its neighbouring countries and thus creates security risks - if not real then perceived - for the countries to the east of the European Union. The EU migration regime is extended to bordering countries which are turned into gate-keepers to protect 'Fortress Europe' from illegal immigrants. These states must also share the burden of asylum-seekers with the EU.

Through an examination of the case study of Ukraine, I will show that European policies of shifting the responsibility of international migration management to other countries can

\footnotetext{
${ }^{3}$ European Neighbourhood Policy, presented by the European Commission in its Communications "Wider Europe Neighbourhood: A new Framework for Relations with our Eastern and Southern Neighbours” (March 2003) and "European Neighbourhood Policy: Strategy Paper" (May 2004), explicitly emphasize the importance of reaching the Union's goals in the area of Justice and Home Affairs through cooperation with and assistance to the EU neighbouring countries. In the ENP Strategy Paper, the Commission says: “The ENP can also help the Union's objectives in the area of Justice and Home Affairs, in particular in the fight against organized crime and corruption, money laundering and all forms of trafficking, as well as with regard to issues related to migration. It is important for the EU and its partners to aim for the highest degree of complementarity and synergy in the different areas of cooperation" (Commission, 2004: 6).
} 
destabilize the societal security of those countries that lack experience and the institutional capacity to effectively deal with international migration. Transit countries frequently do not have the infrastructure, resources, or the juridical norms and institutions necessary to guarantee the protection and security of immigrants and asylum-seekers. This results in the securitization of immigration as a way to attract resources to deal with the problem. Co-operation and assistance, rather than the off-loading of responsibility onto the neighbouring states, should be a priority for the EU if the area of freedom, security and justice is to be shared on the European continent. After the May 2004 enlargement, Ukraine became a new eastern neighbour of the EU. As it is both a sending and a transit country for migrants, its case is interesting to explore. Moreover, as much attention in the literature on Europeanization and the effects of EU enlargement has been devoted to the study of member-states or candidate countries, it is worth exploring what effects EU governance has produced in the neighbouring non-accession countries.

In this paper, the term 'Europeanization' is used as in Grabbe (2006) to denote the EU’s impact on states, not bilateral pressures between them. I maintain that 'Europeanization' encompasses "securitization" because among the "externalities" of EU integration and enlargement is the generalization of the EU's security concerns - at least as these are perceived by the dominant groups in policy-making of the European Union.

In the next section, I briefly sketch the changing nature of member-states' cooperation on immigration and asylum issues. In section three, I review the existing literature on the externalities of the EU migration regime. My analysis supports Lavenex and Uçarer's (2004) argument that the EU common policies develop external dimensions. These may take the form of changes in policy or institutional practices within non-member states ranging from fully 
voluntary to constrained adaptation. This review is followed by the case study of Ukraine, presented in section four.

\section{European Union Cooperation on Immigration and Asylum}

With the end of the Cold War, symbolic openings of borders - through the dismantling of the Berlin Wall and the lifting of the Iron Curtain - created the potential for greater mobility of peoples from ex-Soviet countries across now international borders. At the same time, there was a shift in the attitudes of the Western public and governments to the issue of international migration (i.e. from the politics of protection to the politics of containment), accompanied by the discourse of asylum abuse and the impossibility of differentiating between political and economic migrants. Growing anti-immigrant sentiments were galvanized and brought into the political arena by extreme right parties in a majority of the European countries (e.g., Austria, Belgium, France, Denmark, Italy). The end of the Cold War also brought about new dimensions in security discourse. State security, usually described in military terms, was challenged, and complemented by collective- or individual-based approaches, placing greater emphasis on human security. The growing perception of population displacement as an economic and social security threat to the international order amounted to a new security paradigm in the management of international migration. The discourse on migration has been highly securitized placing immigrants - both refugees and economic migrants - into the category of 'security threats'.

The beginning of cooperation among EU member-states on the issue of immigration-assecurity can be traced back to the mid-1980s. ${ }^{4}$ The Single European Act (1986) aimed to achieve

\footnotetext{
${ }^{4}$ Lavenex and Uçarer (2003) and Geddes (2003) mention that since the 1970s, member-states have cooperated on
} 
freedom of movement for goods, capital and labour within the European Community (EC), and it reaffirmed the member-states' commitment to establish a Single European Market, that necessitated the creation of a common security regime. The Schengen Agreement, signed in 1985 by five EC countries (France, West Germany, Belgium, Luxembourg, and the Netherlands), was drafted to eliminate internal border checks between the signatory states. Order and security were to be reconciled with freedom of movement for EU nationals and third-country nationals legally residing in the territory of a member-state by means of increased and improved coordination among the police, customs and the judiciary of the signatory EU states and third countries. The EU external borders were to be strengthened through the sharing of best practices of border checks and surveillance, the provision of common training and education for border personnel, and the introduction of measures necessary to combat terrorism and organized crime, illegal migration, and trafficking in goods and human beings. The Schengen Information System (SIS) was introduced to share information on asylum claims, illegal migrants, and any other required information. The fortification and increased policing of external borders was justified on the grounds that threats were emanating from organized crime, terrorists, illegal migrants, and traffickers of drugs, goods, and humans. Similarly, immigration was criminalized by linking the entry of illegal immigrants into the EU with the cross-border activities of organized crime networks. European governments sought to cooperate on border control and illegal entry measures, framing them as collaboration on internal security (see Mitsilegas et al., 2003; Bowsell, 2003).

internal security measures. The Trevi group was formed to discuss state responses to terrorism, but through the 1980s, it provided a forum for additional discussion between the member-states on issues of EU integration. Geddes points out that the Trevi group "provided a 'security' frame into which migration issues were inserted” after they appeared on the political agenda in the late 1980s (2003: 130). 
Accordingly, immigration policy was a national prerogative from 1957 to 1986 (Geddes, 2003). The next period (1986-1993) was characterised by informal inter-governmental cooperation with confidential negotiations held behind closed doors, outside of the institutional framework of the EU. In 1990, the Dublin Convention was drafted and negotiated, introducing new asylum processing measures and the 'safe third country' status, allowing the negotiation of readmission agreements with third countries. In Geddes' view, the Dublin Convention facilitated the "off-loading” of responsibility for managing migration to "a Central and Eastern European 'buffer zone’” (2003: 136). Approved measures on asylum processing had a significant effect on Central and Eastern European countries that had to adapt these measures as one of the requirements for EU membership, without being able to partake in the negotiation process and with no option to opt out. Thus, the Dublin Convention turned these countries into "buffer zones” that were created to control migration and absorb immigrants from the EU; asylumseekers entering the EU from these 'safe countries' could be returned back in accordance with readmission agreements. Security-centred measures to combat immigration were prevalent during this period, resulting in highly restricted access to the European space for those who were unwanted.

Since 1993, the member-states have started formal intergovernmental cooperation on asylum and immigration policies. The Maastricht Treaty (1992) established an intergovernmental pillar dealing with Justice and Home Affairs (JHA), as well as the Common Foreign and Security Policy (CFSP). The Maastricht Treaty recognized the issues of common concern for the EU member-states, such as: asylum policy; external frontiers; immigration policy and policy regarding third-country nationals (TCNs); conditions of TCNs' entry and movement within the 
EU; and combat against unauthorized immigration, residence, and work by TCNs (Geddes, 2003: 135). The 1997 Treaty of Amsterdam declared the EU “an area of freedom, security and justice” and created a Directorate-General for Justice and Home Affairs (CEU 1999b, Art. 2, referred to in Lindstrøm, 2005: 591). The Treaty incorporated the Schengen acquis as part of the EU legal framework under a separate Title IV. The Amsterdam Treaty also stipulated that applicant countries must accept Schengen acquis in full and conferred the authority for negotiating readmission agreements to the European Commission.

An essential step forward in the development of a common approach was the first European Council Meeting on Justice and Home Affairs in Tampere in 1999. The summit meeting of heads of government called for a common approach to asylum and migration issues with an emphasis on partnership with countries of origin and transit of migrants, improved and effective asylum measures, and fair treatment for third country nationals who legally reside in the member-states. It was agreed to incorporate standard readmission clauses as a part of all association and cooperation agreements concluded with third countries. Since then, in its international cooperation, the EU has focused, on the one hand, on the development and implementation of common policies and approaches to deal with Justice and Home Affairs (JHA), and, on the other hand, on "cooperation with migrant-sending or transit countries to control, contain or prevent migration and refugee flows” (Boswell, 2003: 99). The Hague Programme (2004) has further developed the common management of migration, the setting up of a common asylum regime, the equitable treatement of the third-country nationals, and the partnership with third countries in managing migration.

The European Commission and member-states have focused on the development of EU 
policies to halt immigration (internal security) and to eliminate the root causes of immigration through external policies of assistance and humanitarian aid (external security). The European Commission (2004) emphasized prevention as a viable option for addressing the causes of immigration and forced displacement through development assistance and humanitarian relief efforts and through bilateral agreements with immigrant-sending, refugee-producing, and transit countries. Lindstrøm's interpretation is that "current policy methods and instruments work to establish legitimacy for the denial of protection and the conclusion of readmission agreements, with a view to shifting responsibility away from the European territorial core” (2005: 588).

Bowsell (2003), in turn, distinguishes three types of policy goals which European national governments are pursuing through international cooperation in the realm of international migration: 1) control of illegal entry and human trafficking; 2) "burden-sharing”, and; 3) migration prevention. While European governments have been working to harmonize their immigration and asylum policies in order to distribute responsibilties for illegal migrants and asylum-seekers between member-states, in their relations with third countries the EU and member-states have been mainly focused on border control and law enforcement issues. Lindstrøm has characterized these practices this way: "migration control and law enforcement may be described as having been outsourced to third countries in exchange for intensified trade and development cooperation” (2005: 592). This characterization is accurate in light of the new European Neighbourhood Policy and the development of bilateral agreements and action plans with each of the neighbourhood countries because conditionality and assistance have become the main tools in bilateral relations. The external dimension of maintaining the EU's “area of 
freedom, security and justice” has become increasingly important in EU governance. ${ }^{5}$

\section{The Externalities of the EU Immigration and Asylum Policy}

European integration is strongly founded on the idea of common security - political, economic, and cultural. Viewing immigrants as a threat to the existing European social order has resulted in a highly defensive and exclusive approach to European security in which emphasis is placed on control (both internal and external) and policing. As well, governments fear having border controls less stringent than their neighbours, lest their countries become attractive destinations for refugees and illegal immigrants (Lindstrøm, 2005). Van Selm (2005) observes that the movement of people across geo-political frontiers can be viewed either as strengthening or weakening regional security. In the case of the EU, we see that the movement by EU nationals within the European Union is not subjected to the same degree of critical scrutiny or suspicion as the entry into the EU space by non-nationals. ${ }^{6}$ Nationalist-populist discourse has associated "non-European" immigrants, in particular, with a host of societal risks, from increasing unemployment to terrorism. Member-states press neighbouring countries to increase surveillance

\footnotetext{
${ }^{5}$ As an example, A Strategy on the External Dimension of the Area of Freedom, Security and Justice was developed by the European Commission in October 2005 at the request of the European Council of 16-17 June 2005, as a part of the Hague Programme aimed at strengthening freedom, security and justice in the European Union. According to this Strategy, cooperation with third countries on migration, asylum and border management is among the top political priorities of the EU (Commission, 2005a). Further, the Commission has developed The Thematic Programme for the Cooperation with Third Countries in the Areas of Migration and Asylum (January 2006) "to provide support for third countries so that they can better manage migratory flows” (Commission, 2006). Funding of this Programme will be allocated to eligible countries taking into account respect for democratic principles and the rule of law and records on human and minority rights.

${ }^{6}$ One can argue that even intra-regional migration in the EU can be considered negative when people see "the migration of the European citizens as a threat, when they perceive job 'stealing' taking place, or migration for primarily tax and social security purposes” (Van Selm, 2005: 13). The recent rhetoric of the EU members regarding the freedom of movement of nationals from newly admitted CEE countries is worth mentioning, as well. Although these people became new EU citizens, they, evidently, cannot fully enjoy the rights and freedoms of movement of other EU citizens without being ‘tested' and 'constrained' for a while - at least two years.
} 
and control of borders in order to guard the European "area of freedom, security, and justice." Such a situation might cause the transit and buffer zones to receive larger amounts of labour migrants and asylum-seekers wishing to enter the EU.

A convincing account of the externalities of the EU migration regime has been suggested by Lavenex and Uçarer (2004). Drawing on the literature on Europeanization and policy transfer, these authors argue that EU immigration policies produce external effects on non-EU states that deal with the Union. Although Europeanization has been narrowly defined as "the impact of European integration at the national level of the member-states (Knill and Lehmkul, 2002: 255), its dynamics can also be extended to states other than EU member states in so far as they refer to 'a process of change in national institutional and policy practices that can be attributed to European integration”” (Hix and Goetz, 2000: 27; cited in Lavenex and Uçarer, 2004: 419). As the European Union has significantly increased its image and influence in the international arena, it is now involved in institutional cooperation with many other states. As a result, EU immigration policies have implications for destination countries of asylum-seekers and immigrants, as well as for the countries of their origin and transit.

The question then is: how can we determine that changes happening in the policies of non-member states can be attributed to European integration and/or pressures from the EU? As Lavenex and Uçarer (2004) suggest, EU policies can be designed intentionally to have external effects on third countries (i.e. to purposefully export common policies through bilateral or multilateral agreements). They may also reflect "unintended consequences of other intentional activities” and cause the extension of EU policies to the countries with which the Union 
co-operates (2004: 420). In turn, another important dimension is whether the effects in third countries occur because of states’ voluntary action or a coerced adaptation and change. ${ }^{7}$

Lavenex and Uçarer suggest, from an institutionalist perspective, that non-member states’ established institutional linkages with the European Union "indicate the content and scope of [policy] transfer intended on the part of the EU” (2004: 423). These linkages correspond to the geographic proximity of a country to the EU, and determine the scope of externalities felt by each country. ${ }^{8}$ EU policies directed at the management of migration flows will necessarily affect both the countries of destination and the countries of origin of the migrants:

Changes in the immigration policy of one country have implications for the immigration policy of other countries: a more permissive policy may lead to a reduction of immigration flows in neighbouring countries, while a more restrictive policy may increase the number of migrants seeking entry in other countries. ... Both the territorial scope of the EU and its importance as a major destination for voluntary and forced migrants imply that common policies aiming at the extension or reduction of immigrant inflows will necessarily have implications for other countries, both countries of destination and of origin (Lavenex and Uçarer, 2004: 425).

As has been suggested in the Europeanization literature (see Grabbe, 2003; Grabbe, 2006;

Schimmelfennig and Sedelmeier, 2005), a country’s aspiration to EU membership provides the European Union with significant leverage for the transfer of European rules, norms, and policies, as well as for the shaping of that country's administrative and institutional structures. As the negotiations on the membership of the newly admitted ten Central and Eastern European countries (CEECs) showed, the European Commission was able to use membership status as the

\footnotetext{
${ }^{7}$ Lavenex and Uçarer "distinguish between four forms of policy adaptation and transfer: adaptation through unilateral emulation, adaptation through externalities, and two forms of policy transfer through conditionality, one where the changes fit the domestic interests, and one when the latter occur under pressure” (2004: 420 - 21).

${ }^{8}$ According to Lavenex and Uçarer (2004), there are five types of institutional affiliation with non-EU countries based on the types of associational agreements: 1) close association (Norway and Switzerland); 2) accession association (Central and Eastern Europe); 3) pre-accession association (Turkey and Balkan countries); 4) neighbourhood association (Ukraine, Russia, Moldova, Maghreb countries); and 5) loose association (the African, Caribbean and Pacific countries).
} 
"carrot" in protecting its interests. The EU frequently used conditionality as a strategy of reinforcement by reward to induce compliance (Schimmelfennig and Sedelmeier, 2005). Grabbe (2006), however, suggests that in cases where the European institutions and governments were undecided and ambivalent on how to proceed in negotiations, the CEECs were able to use these inconsistencies to lessen the effect of the EU's accession conditionality and proceed with their interests. $^{9}$

While conditionality played a great role in the European Commission's negotiation with the acceding CEECs, its effects were less significant in the case of ex-Soviet countries, or the Commonwealth of Independent States (CIS). As both Grabbe (2006) and Kelley (2006) observe, the EU's conditionality has not been successful and worked only partially in the CIS where domestic politics determined a major cause of whether EU values and norms have been adopted. In the case of the current neighbouring states (Moldova, Belarus, Russia, and Ukraine), where association agreements cannot yet be put on the table for discussion, the EU does not have the same leverage to impose its internal policy agenda. The European Neighbourhood Policy (ENP), however, was designed to "take the opportunity offered by enlargement to enhance relations with its neighbours on the basis of shared values" and "to avoid drawing new dividing lines in Europe and to promote stability and prosperity within and beyond the new borders of the Union" (Commission, 2003). As Kelley (2006) suggests, the European Commission, viewing enlargement as the most succesful EU foreign policy, drafted the ENP using the model - and

\footnotetext{
${ }^{9}$ Although the Schengen acquis have to be fully implemented before a new member can enjoy all four freedoms of movement, some of the CEECs were able to negotiate the gradual adoption of these acquis. While visa regulations and border control mechanisms were adopted by the candidate countries by the accession date, all the rest of the Schengen acquis should be implemented by the date at which a country becomes a member of the Schengen visa regime. Newly admitted countries do not belong to the Schengen visa regime yet.
} 
sometimes the content - of the previous accession agreements. ${ }^{10}$ Yet, the fact that there is no promise of institutional association can be viewed as an attempt "to find a substitute for the leverage provided by the promise of membership” (Lavenex, 2005: 105).

The reality, nevertheless, is that following the last enlargement to the east, the EU now borders countries that are viewed as 'soft' security threats - as countries of both the origin and transit of illegal or irregular migrants, asylum-seekers, criminals, and drug and human traffickers. As these issues are at the core of the EU JHA policy, cooperation with the neighbouring countries in this realm is important. The rest of this essay explores EU-Ukraine cooperation on justice and home affairs, with particular attention to immigration and asylum issues.

\section{The Externalization of International Migration Management: A Case Study of Ukraine}

As was mentioned above, the case of Ukraine is interesting and important to examine because Ukraine is a country of transit for illegal immigrants and asylum-seekers and also a source of both legal and illegal immigrants. Its close geographic location to the European Union and the opening of borders since Ukraine’s 1991 independence has turned the country into a transit area for illegal immigrants and asylum-seekers from Africa, Asia, and the Middle East. On the other hand, socio-political transformations in this post-Soviet country have liberalized its borders for the legal movement of people, and economic crises have pushed some Ukrainians to

\footnotetext{
${ }^{10}$ As Kelley's (2006) analysis of primary documents and interviews with Commission officials, officials of ENP countries, and human rights experts shows, "the Commission's conceptualization and development of the ENP has drawn on multiple elements from the past enlargement experiences” (2006: 30).
} 
seek jobs and earnings abroad. Ukraine’s long and poorly guarded frontiers ${ }^{11}$ (with corrupt officials engaged in the illegal transportation of migrants) and the absence of readmission agreements with neighbouring countries make it a widely-used transit country (Uehling, 2004; Polyakov, 2004; ICMPD, 2005). After the May 2004 enlargement Ukraine’s western border has become the eastern frontier of the strictly guarded European Schengen area. This, in turn, causes additional pressures created by the European Union on Ukraine to guard the European territory, as well as to keep the Ukrainian territory in check. ${ }^{12}$

Official statistics and estimates of the numbers of Ukrainian migrants and transit nonUkrainian migrants vary greatly. Polyakov (2004: 18-19) points out that the number of illegal migrants transiting through Ukraine and detained by Ukrainian border guards has increased from 148 persons in 1991 to approximately 14,646 in 1999. Polyakov mentions Afghans, Indians, and Chinese among the most frequently detained groups. According to the 2004 Migration Report of the State Committee on Nationalities and Migration, the number of people trying to cross Ukrainian borders illegally in 2004 for migration purposes was 2,918 persons (of these: 610 Chinese, 532 Russians, and 319 Georgians). The largest number (1548 persons) of illegal migrants was detained crossing the Ukrainian-Slovak border. Elsewhere, 769 were arrested on the Ukrainian-Polish border and 391 on the Ukrainian-Russian border (DCNM, 2005). The Report also mentions that, according to the Ministry of Internal Affairs, 12,271 persons were

\footnotetext{
${ }^{11}$ Ukraine has a $103 \mathrm{~km}$ border with Hungary, a $526 \mathrm{~km}$ border with Poland, a $97 \mathrm{~km}$ border with Slovakia, and a $169 \mathrm{~km}$ border to the south and a $362 \mathrm{~km}$ border to the west with Romania.

${ }^{12}$ According to Malynovska (2006), during the Soviet times, immigration into Ukraine was prevalent over emigration and was predominantly composed of ex-Soviet nationalities. In the early 1990s, the repatriation of nationalities that lived in the ex-Soviet republics, as well as the inflow of refugees fleeing armed conflicts and civil wars in some post-Soviet states, dominated the migration patterns. Since the mid-1990s, the ethnic constitution of people immigrating to Ukraine has changed in favour of those groups that had not historically resided there (i.e. ethnically and culturally different immigrants from Asia, Africa, and the Middle East).
} 
deported from Ukraine in 2004. However, Polyakov (2004) and Pidluska (2001) refer to government estimates of illegal entrants as high as 35,000 to 50,000 per year. Malynovska (2006), in turn, points out that between 1991 and 2003, Ukrainian border-guards detained about 100,000 illegal migrants trying to cross Ukraine’s western border. ${ }^{13}$

While it is hard to argue about the intention of people on the move, some studies (see Uehling 2004) show that many illegal immigrants, detained crossing Ukraine’s borders, had no intention to stay in Ukraine. Hence, this country is turned into a 'buffer zone,' through which routes for illegal migrants into the European Union are laid. Also, it becomes a space for stopping the illegal migrants and asylum-seekers unwanted in the EU. ${ }^{14}$

The European Union-Ukraine co-operation has been based on the following major agreements: the Partnership and Cooperation Agreement (PCA) of 14 June 1994; A Common Strategy on Ukraine of December 1999; the EU-Ukraine Action Plan on Justice and Home Affairs (December 2001); and the EU-Ukraine Action Plan (February 2005) adopted in the framework of the ENP. Both the PCA (1994) and The Common Strategy on Ukraine (1999) emphasize support for democratic and economic transition in Ukraine, cooperation to ensure stability and security on the European continent, and increased political, economic, and cultural cooperation.

The priorities of cooperation in the framework of the EU-Ukraine Action Plan on Justice and Home Affairs (2001) were determined at the Ministerial level in 2002, with its progress

\footnotetext{
${ }^{13}$ It is hard to predict the total number of illegal migrants when many of them enter the Ukrainian territory legally but then violate their status and become illegal (i.e. without a proper documentation and allowance to stay). Further, Ukraine has no single government body responsible for all migration-related issues. Rather, migration-related responsibilities are divided among eight executive agencies (Polyakov, 2004).

${ }^{14}$ Vachudová (2000) suggests that the EU builds relationships with its southern and eastern neighbours on a basis of "proximity policy" that accounts for their political and strategic importance as trading partners and as European 'buffer zones.'
} 
reflected in the scoreboard. As mentioned on the official web-site of the European Commission: “This Action Plan [2001] seeks to impart on Ukraine the principles inherent in the EU area of freedom, security and justice.” The co-operation between Ukraine and the Union on JHA has focused on negotiating an EU-Ukraine readmission agreement and better migration management, improving border management, judicial reform, implementing the rule of law, and eliminating organized crime and terrorism (Commission, 2001). The 2001 Action Plan was incorporated as a part of the EU/Ukraine Action Plan agreed upon in the framework of the ENP in February 2005 (Commission, 2005b).

In the EU-Ukraine co-operation, significant efforts are directed at the harmonization of legislation, maximization of government capacity, and promotion of cross-border cooperation. Measures to "combat” illegal/irregular immigration have also received a great deal of attention. In the framework of the EU-Ukraine Action Plan on JHA (2001), 'migration and asylum' and 'trans-border cooperation and visa policies' were listed as two first areas of co-operation (see Commission 2001). The EU and Ukraine have closely cooperated on such issues as visa regulation, border management, irregular migration, asylum regulation, human trafficking, and return and readmission policies.

Ukraine, faced with the problem of migration management, adopted its first laws to control migration from ex-Soviet countries and to regulate the status of citizens, foreigners, and persons without statehood in the early 1990s. In 1993, the Ukrainian parliament, reacting to increasing number of asylum-seekers from the ex-Soviet republics, passed the "Law on Refugees”. It was later replaced by a new law on refugees, which allowed Ukraine to accede in January 2002 to the 1951 UN Convention on Refugees and its 1967 Protocol. In addition to that, 
other major laws in the realm of migration management were adopted (e.g., “On Immigration,” a new law “On Citizenship”, the amendments to the law “On the Legal Status of Foreigners”, “On the State Borders of Ukraine”). All these laws were adopted in full compliance with EU standards. According to Chumak (2003), such convergence of the Ukrainian law with the related European law on the management of legal migration was voluntary, but also necessitated by the communitarisation of the Schengen acquis in 1999. In addition, some requirements (e.g. to improve the law on refuge and asylum issues; to establish a single governmental body responsible for migration-related issues; to improve border management) were stipulated as a part of the EU-Ukraine Action Plan on JHA. Therefore, such policy transfer can be viewed as a mix of voluntary and involuntary adaptation by conditionality and as a response to the externalities of the EU migration policies. ${ }^{15}$

Using the principle of conditionality, the European Union has made a readmission agreement a prerequisite for Ukraine to be granted a simplified visa regime for its citizens. As a country of the origin and transit of migrants, Ukraine, evidently, will not benefit from signing such an agreement. Nevertheless, it is forced to comply in order to get its reward - a simplified visa regime for its citizens. To lessen this conditionality, Ukrainian government seeks the support of the European Commission and governments to negotiate readmission agreements with its neighbours (policy emulation). ${ }^{16}$ And similarly to the newly accessed CEECs, because of its future prospect for European integration and its national interests and security, Ukraine is willing

\footnotetext{
15 The European Neighbourhood and Partnership Instrument (ENPI) will replace such geographical assistance programmes as TACIS and MEDA in 2007. It will be specifically "designed to target sustainable development and approximation to EU policies and standards” and will assist in implementing the European Neighbourhood Policy.

${ }^{16}$ Although Ukraine has successfully signed such agreements with Georgia and Moldova, it has not been successful in completing such agreements with its biggest suppliers of illegal migrants - Belarus, Russia, China, and
} 
to trade freedom of movement of its citizens for restrictive measure for citizens of those countries, which are on the EU’s “black” visa list.

Willing to join the EU, Ukraine's new pro-European leadership seeks to repair a relationship of mistrust that had developed as a result of Ukraine's inconsistency in democratizing and transforming the country since the 1990s. Ukrainian authorities are focused on improving legislative base, strengthening border cooperation with neighboring countries, and improving the organizational and institutional framework for dealing with illegal immigration. More attention has been paid to increasing the state's capacity in assisting individuals detained while transiting through Ukraine. Restrictive immigration measures, however, are on the rise, and detention and deportation are used by Ukrainian authorities as the main policy instrument used to halt immigration (Human Rights Watch, 2005).

It is important to note that the securitization of immigration in Europe has created a narrow understanding of immigration as a law enforcement issue (Uehling, 2004; Guiraudon, 2006). As a result, immigrants are perceived by the European public as posing societal risks. Although the situation with immigrants in Ukraine has not yet been thoroughly studied, the issue of immigration is also interpreted by some officials and bureaucrats as a "security concern." Polyakov (2004), for example, emphasizes the criminal nature of transit illegal immigrants and describes them as a significant challenge for Ukraine:

In general, growing illegal migration to Ukraine contributes to the growth of criminality and corruption, and to overloaded social support systems and infrastructures. It threatens cultural identity and can bring social and ethnic tensions. It is not a fantasy any more to conclude that illegal migrants could well have terrorist backgrounds and intentions. In the end, the settling of illegal migrants in Ukraine does

Uzbekistan. It aims to work out the agreement with Russia before signing an agreement with the EU, as Russian undemarcated borders with Ukraine pose the largest concerns regarding illegal transit migration (ICMPD, 2005). 
not support economic development of the country (unlike the case of the European Union, where cheap labor is in demand), and it generally threatens Ukraine's relationship with the EU in future (Polyakov, 2004: 28). ${ }^{17}$

This very negative portrayal of a generalized “illegal” is not unique to Ukraine. Mass media frequently report stories on immigrants from Asia and Africa bringing unknown diseases and “exotic” religions and customs, or being involved in drugs or contraband business (Pidluska, 2001; Uehling, 2004). In its report, the State Committee on Nationalities and Migration reports on crimes committed by illegal immigrants, threats to public health, and the number of detentions and administrative fines (DCNM, 2005). These claims have not been substantiated by actual research on the situations and activities of immigrants. Uehling (2004) points out that xenophobic and discriminatory statements about asylum-seekers and refugees were made during her interviews in Ukraine, even by state officials who deal with these groups.

Combined with its policies, the EU exports its social construction of immigrants as inherent "threats" who must be combatted, stopped at the borders, and deported. Because immigration is dealt with on the level of justice and internal affairs officials, border guards, and policemen, the Ukrainian public receives its information about immigrants from these law-andorder authorities. Ukrainian officials, who co-operate with EU authorities in the area of migration and asylum management, learn and adopt both positive and negative practices for dealing with migration. They partake in the discursive construction and perception of an immigrant as a "threat" to Ukrainian society, while no empirical evidence exists to prove or disprove the existence of such threats. Concurrently, whereas the Ukrainian state seeks the support of the European Union in combating illegal migration throughout its territory, it portrays

\footnotetext{
${ }^{17}$ Interestingly enough, Ukrainian immigrants, who are also frequently illegally present and employed in EU countries, are described by Polyakov as workers who should be socially and legally protected.
} 
Ukrainian labour migrants (either legal or illegal) as hard-working persons undergoing hardships abroad in order to provide for their families. Such 'doubled' construction of 'immigrants' merits further study.

Evidently, it is not appropriate to consider Ukraine a 'blank page' on which the EU discourse on immigration (hardly homogeneous but, nevertheless, heavily influenced by populist anti-immigrant rhetoric) is easily written. Nonetheless, I would argue that EU practices and policies set models for other countries to follow. As for indigenous influences on the Ukrainian national discourse on immigration, it should be remembered that Ukraine is an immigrantsending country and it does not yet have a need for low-paid immigrant labour. Unlike in western Europe, immigration has not yet become "the" issue in electoral campaigns, and it is hardly debated by the Ukrainian public. ${ }^{18}$ Nevertheless, the Ukrainian press has a tendency to mainly focus on negative aspects of immigration, connecting it to crime, drug use, and public health issues. This tendency would be rather interesting to account for by comparing mass media discourse with public attitudes towards immigrants and foreigners. ${ }^{19}$ In addition, political elites' willingness to show Ukraine's ability to fight illegal migration leads politicians to focus on the association between immigration and "security threats"; little distinction is being made between asylum-seekers and economic immigrants. Refugees and asylum-seekers pose a problem to the state because of the state's lack of resources and institutional capacities to provide these people with the level of support to which Ukraine has committed.

\footnotetext{
${ }^{18}$ It should be mentioned, however, that in the 2006 parliamentary campaign in Ukraine, some marginal extreme right parties, such as "Freedom" and UNA-UNSO, did campaign using anti-immigrant slogans and attracting the public's attention to the presence of "foreigners" and "occupants" in Ukraine. It will be interesting to follow if and how these issues will develop into "the" topic on which electoral campaigns will be built in Ukraine.

${ }^{19}$ Braichevs'ka et al. (2003) did interviews with local citizens and experts in Kyiv, the capital of Ukraine. Their research showed that the majority of the Kyivan population was not concerned about the arrival of immigrants from Africa, Asia, and the Middle East.
} 
As Human Rights Watch (2005) reports, Ukraine - which accepts returnees from EU member-states and is now working on an EU-wide readmission agreement - violates the human rights of returned immigrants and asylum-seekers. There are no satisfactory institutional, legal, and material resources to guarantee the security of either illegal immigrants or genuine refugees and asylum-seekers, nor is the assistance from the EU adequate. Because of Ukraine’s aspiration to join the EU, it continues to accept returnees from the EU member-states. As the HRW research shows, there is hostility towards foreigners in Ukraine, especially toward Chechens and Afghans who face discrimination and deportation, even when they have circumstances to become UNHCR-recognized refugees.

As mentioned above, a country's aspiration to membership in the European Union provides the latter with significant leverage for transferring rules, norms, and policies, as well as in shaping administrative and institutional structures (Grabbe, 2003). Although the local elites' willingness to adapt domestic policy to EU requirements and priorities might be viewed as an effective strategy for accelerating association status, this strategy may also be viewed negatively because it displaces a more autonomous policy process, as well as alternative policy approaches. While the EU Neighbourhood Policy can be regarded as a process of bringing Ukraine closer to the EU in terms of political and economic cooperation, the Policy does not satisfy the Ukrainian goals of association. The EU-Ukraine Action Plan in the framework of the ENP is not considered to be an adequate foundation for the development of EU-Ukraine cooperation, as it does not acknowledge Ukraine as an integral part of a united Europe. Rather, the ENP is viewed as one of the strategies that will prepare Ukraine for European integration and will allow it to enter into a qualitatively new legal framework of relationships with the EU. According to the Minister of 
Foreign Affairs of Ukraine, Borys Tarasyuk, the ENP should be replaced by the association agreement that will set clear perspectives for Ukraine’s membership in the Union. ${ }^{20}$

There is a clear divergence of interests between the EU and Ukraine; while the EU wants Ukraine to put resources into the policing of its western borders, Ukraine is interested in demarcating and maintaining control of its eastern borders, which are the main access points for illegal migrants and criminal groups. At the same time, Ukrainian authorities do not want to allow for new "curtains" or "walls" to be built on its western frontiers. For Ukraine, the Schengen acquis must mean not only border security, but also the opening of doors to Europe for its citizens and businesses (i.e. special visa rules for Ukrainian business persons, diplomats, politicians, academics, and students). The European Union, especially the member-states from Central and Eastern Europe, have similar interests. They want to avoid new dividing lines being erected across the borderland ethnic communities along the European external border, which, consequently, might challenge cross-border economic, cultural, and scientific exchanges. Therefore, the cross-border co-operation programmes (introduced by the Union to strengthen the eastern borders of the EU candidate countries and to establish regional partnership between accession countries and their neighbours) are beneficial both for the EU and Ukraine.

Although "the neighbourhood association illustrates the limits of a strong unilateral approach favoring one-sided EU interests” (Lavenex and Uçarer, 2004: 434), the “joint ownership” of the action plans and individual approaches to each of the neighbours create a virtual space for dialogue and cooperation. Nevertheless, the European Neighbourhood and Partnership Instrument (ENPI), that will replace such geographical assistance programmes as

\footnotetext{
${ }^{20}$ Such a position was vocalized by Borys Tarasyuk at the international conference "Ukraine and European Integration: Challenges and Opportunities” (Kyiv, Ukraine, 6 July 2006).
} 
TACIS and MEDA in 2007, will be specifically “designed to target sustainable development and approximation to EU policies and standards” and will assist in implementing the European Neighbourhood Policy (The ENP web-site). Its application will be tied to conditionality of democracy and human rights development. In this light, EU policy-transfer to neighbouring states that have or not legal framework for dealing with the flows of irregular migrants and organized crime groups seem inevitable if neighbours want to receive development assistance and grant funding. Thus, the Commission will receive additional leverage over the countries whose integration perspectives are questionable. Further developments into how non-member and non-accession countries adapt to European integration will be interesting to follow, especially in light of the new environment of international security concerns and the debates about the future of the EU project.

\section{Conclusions}

The management of EU external borders is greatly dependent on its integration and enlargement processes. The conceptualization of European identity, which accompanies the process of integration, and the conceptualization of threats that endanger security, either societal or state, determine the relationship of the EU and its member-states with their neighbouring countries. Perceived "security threats” from immigrants create more anxiety and fear among the public as European frontiers come closer to the countries of origin of these "threats." The securitization of immigrant flows and the discursive construction of immigrants as "criminals", "bogus refugees”, or “intruders”, deprived of human faces and problems, takes away these people’s protection. 
The politics of containment practiced and promoted by the EU has both positive and negative effects. On the one hand, it allows countries in need to receive more substantial development assistance but, on the other hand, it takes away the right of people residing in those countries to seek asylum and a safer life in the European space. At the same time, the pressure that the EU puts on its neighbours to implement similar practices for securing frontiers impels the expansion of an immigration regime that is discriminatory and exclusionary towards new territories. New transit and buffer zone countries, which lack efficient institutional and infrastructural frameworks for dealing with illegal migration and crime groups, may face further societal disturbances if the problem of international migration is not adequately addressed by the international community. The ENP framework and differential approach to every neighbouring country proposed by this Policy has become an important platform for the EU's co-operation with its neighbours. It will produce positive outcomes if the principles of mutual co-operation and material, technical, legal, and educational assistance to transit countries and the countries of origin of migrants are followed. 
Bibliography

Bort, Eberhard. 2005. "European Borders in Transition: The Internal and External Frontiers of the European Union.” In Holding the Line: Borders in a Global World, eds. Heather N. Nicol and Ian Townsend-Gault, 63 - 89. Vancouver: UBC Press.

Boswell, Christina. 2003. European Migration Policies in Flux: Changing Patterns of Inclusion and Exclusion. The Royal Institute of International Affairs, European Programme. Blackwell Publishing.

Chumak, Victor. 2003. “Zaprovadzhennya Shengens'koi Ugody v Krainax CSE ta Baltii: Naslidky dlya Natsional'noi Migratsijnoi polityky Ukrainy" (Accession to the Schengen Agreement by the CEECs and the Baltic States: Consequences for the National Migration Policy of Ukraine). Perspektyvni Doslidzhennya 20 (January): 2-18.

Commission of the European Communities. 2001. EU-Ukraine Action Plan on Justice and Home Affairs (in Ukrainian), http://ukraine-eu.mfa.gov.ua/eu/ua/publication/print/2233.htm (May $1,2006)$.

Commission of the European Communities. 2003. Communication from the Commission to the Council and the European Parliament, Wider Europe - Neighbourhood: A New Framework for Relations with Our Eastern and Southern Neighbours, COM (2003) 104 Final.

Commission of the European Communities. 2004. Communication from the Commmission, European Neighbourhood Policy Strategy Paper, COM (2004) 373 Final.

Commission of the European Communities. 2005a. Communication from the Commission A Strategy on the External Dimension of the Area of Freedom, Security and Justice. COM (2005) 491 final.

Commission of the European Communities. 2005b. ENP EU/Ukraine Action Plan, http://ec.europa.eu/comm/world/enp/pdf/action_plans/ukraine_enp_ap_final_en.pdf (April 28, 2006).

Commission of the European Communities. 2006. Thematic Programme for the Cooperation with Third Countries in the Areas of Migration and Asylum, COM (2006) 26 final, http://eur-lex.europa.eu/LexUriServ/site/en/com/2006/com2006_0026en01.pdf (July 28, 2006).

Derzhavnyy Comitet Natsional'nostej ta Migratsii Ukrainy. 2005. Migratsijna sytuatsia $v$ Ukraini za 2004 rik (Migration Situation in Ukraine in 2004). http://www.scmn.gov.ua/ua/a?migration_way (January 20, 2006).

Geddes, Andrew. 2003. The Politics of Migration and Immigration in Europe. London, Thousand Oaks, New Delhi: SAGE Publications.

Grabbe, Heather. 2003. "Stabilizing the East While Keeping Out the Easterners: Internal and External Security Logics in Conflict.” In Migration and Externalities of European Integration, eds. Sandra Lavenex and Emek M. Uçarer, 91-104. Oxford: Lexington Books.

Grabbe, Heather. 2006. The EU's Transformative Power: Europeanization through Conditionality in Central and Eastern Europe. Houndmills, Basingstoke: Palgrave Macmillan. 
Huysmans, Jef. 2000. “The European Union and the Securitization of Migration.” Journal of Common Market Studies 38 (5): 751-77.

Human Rights Watch. 2005. Ukraine: On the Margins. Rights Violations against Migrants and Asylum Seekers at the New Eastern Border of the European Union. Vol. 17, No.8, http://hrw.org/reports/2005/ukraine1105/ukraine1105.pdf (April 10, 2006).

International Centre for Migration Policy Development. 2005. "Ukraine." In Overview of the Migration Systems in the CIS Countries, 262-286. Research paper, http://www.icmpd.org/default.asp?nav=home\&folderid=-1\&id=543 (January 25, 2006).

Kelley, Judith. 2006. "New Wine in Old Wineskins: Promoting Political Reforms through the New European Neighbourhood Policy.” Journal of Common Market Studies 44 (1): 29-55.

Lavenex, Sandra. 2005. "Justice and Home Affairs and the EU's New Neighbours: Governance Beyond Membership?” In The Area of Freedom, Security and Justice in the Enlarged Europe, ed. Karen Henderson, 89-109. Houndmills: Palgrave Macmillan.

Lavenex, Sandra, and Emek M. Uçarer. 2003. “The Emergent EU Migration Regime and Its External Impact.” In Migration and Externalities of European Integration, eds. Sandra Lavenex and Emek M. Uçarer, 1-13. Oxford: Lexington Books.

Lavenex, Sandra, and Emek M. Uçarer. 2004. "The External Dimension of Europenization: The Case of Immigration Policies." Cooperation and Conflict: Journal of the Nordic International Studies Association 39 (4): 417-443.

Lindstrøm, Channe. 2005. "European Union Policy on Asylum and Immigration. Addressing the Root Causes of Forced Migration: A Justice and Home Affairs Policy of Freedom, Security and Justice?” Social Policy and Administration 39 (6): 587 - 605.

Malynovska, Olena. 2006. "Caught between East and West, Ukraine Struggles with Its Migration Policy.” Migration Information Source, http://www.migrationinformation.org/Profiles/ display.cfm?ID=365 (June 20, 2006).

Mitsilegas, Valsamis, Jörg Monar, and Wyn Rees. 2003. The European Union and Internal Security: Guardian of the People? Houndmills: Palgrave Macmillan.

Pidluska, Inna. 2001. Borderland or Direct Neighbourhood: Ukraine-EU Relations in the Field of the JHA Beyond the EU Enlargement. http://www.policy.hu/pidluska/inna1.html (March 25, 2006).

Polyakov, Leonid. 2004. “Illegal Migration: Ukraine.” European Security 13: 17-33.

Schimmelfennig, Frank, and Ulrich Sedelmeier. 2005. "Introduction; Conceptualizing the Europeanization of Central and Eastern Europe.” In The Europeanization of Central and Eastern Europe, eds. Frank Schimmelfennig and Ulrich Sedelmeier, 1-28. Ithaca and London: Cornell University Press.

Tsoukala, Anastassia. 2005. “Looking at Migrants as Enemies.” In Controlling Frontiers: Free Movement Into and Within Europe, eds. Didier Bigo and Elspeth Guild, 161-192. Aldershot, England: Ashgate Publishing.

Uehling, Greta. 2004. "Irregular and Illegal Migration Through Ukraine.” International Migration 42 (3): 77-109.

Vachudová, Milada Anna. 2000. "Eastern Europe as Gatekeeper: The Immigration and Asylum Policies of an Enlarging European Union.” In The Wall Around the West: State Borders and Immigration Controls in North America and Europe, eds. Peter Andreas and Timothy Snyder, 153-171. Oxford, England: Rowman and Littlefield Publishers.

Van Selm, Joanne. 2003. "Immigration and Asylum or Foreign Policy: The EU's Approach to 
Review of European and Russian Affairs vol. 2 issue 2/2006 C RERA 2006 all rights reserved

Migrants and Their Countries of Origin.” In Migration and Externalities of European Integration, eds. Sandra Lavenex and Emek M. Uçarer, 143-160. Oxford: Lexington Books.

Van Selm, Joanne. 2005. "Immigration and Regional Security.” In International Migration and Security: Opportunities and challenges, eds. Elspeth Guild and Joanne van Selm, 11-27. London and New York: Routledge.

Wæver, Ole. 1996. “European Security Identities.” Journal of Common Market Studies 34 (1): 103-131.

Wæver, Ole, Barry Buzan, Morten Kelstrup, and Pierre Lemaitre. 1993. Identity, Migration and the New Security Agenda in Europe. London: Pinter Publishers Ltd. 